\title{
Influence of Pre-Sampling Handling Duration on Selected Biochemical Indices in the Common Pheasant (Phasianus colchicus)
}

Petr Chloupek ${ }^{1}$, Eva Voslářová ${ }^{1}$, Pavel Suchý Jr. ${ }^{2}$, Iveta Bedáňová ${ }^{1}$, Vladimíra Pištěková1, František Vitula $^{3}$, Jan Chloupek ${ }^{4}$, Vladimír Večerek ${ }^{1}$

\begin{abstract}
${ }^{1}$ Department of Veterinary Public Health and Toxicology, Faculty of Veterinary Hygiene and Ecology, ${ }^{2}$ Department of Human Pharmacology and Toxicology, Faculty of Pharmacy, ${ }^{3}$ Department of Veterinary Ecology and Environment Protection, ${ }^{4}$ Department of Nutrition, Livestock Breeding and Animal Hygiene,

Faculty of Veterinary Hygiene and Ecology, University of Veterinary and Pharmaceutical Sciences in Brno, Czech Republic
\end{abstract}

Received April 4, 2008

Accepted October 1, 2008

\begin{abstract}
The effects of varying periods of pre-sampling handling (1.5 $\mathrm{min}, 3 \mathrm{~min}, 4.5 \mathrm{~min}, 6 \mathrm{~min})$ on selected biochemical indices were monitored in a group of 8-9-month-old common pheasants (Phasianus colchicus) kept at a pheasantry in Jinačovice, Czech Republic. The duration of pheasant handling (capture, restraint, and blood sampling) was positively correlated with plasma corticosterone $(p<0.001)$ and lactate $(p<0.05)$ levels. Negative correlations were found between the handling duration and glucose concentration $(p<0.01)$, and aspartate aminotransferase level $(p<0.05)$ in the blood plasma. A significant increase in corticosterone plasma concentrations and a decrease in glucose plasma concentrations were already found in blood samples taken after 3 min of capture in comparison to blood samples of pheasants taken within $1.5 \mathrm{~min}$.
\end{abstract}

Corticosterone, glucose, blood sample, sampling time, capture, stress

Current scientific research has focused on stress in animals with the aim to identify factors affecting animal well-being, both in captivity and in its natural habitat. Since one of the hallmarks of stress in birds is the release of corticosterone, a member of the glucocorticoid family of steroid hormones, there has been an interest in analyzing corticosterone concentrations in both domestic and wild birds (Romero and Romero 2002). Collecting blood for glucocorticoid analysis that involves capture and handling of birds is at present the most common way of determining corticosterone concentrations, even though there were attempts to avoid possible stressful effects of blood sampling per se by measuring faecal concentrations of glucocorticoid metabolites (Kotrschal et al. 1998; Harper and Austad 2000; Goymann et al. 2002).

Evaluating an animal's response to stress-inducing events requires knowledge of the baseline concentrations of the monitored indicators - presumed to reflect pre-stress levels (Romero et al. 1997; Wing field and Romero 2001). It is well documented that in particular the duration of pre-sampling handling influences hormonal levels, and corticosterone concentrations quickly rise (Romero 2004; Romero and Reed 2005; Voslářová et al. 2008). Romero and Romero (2002) emphasized that the elapsed handling time before sampling is a critical variable in the stress responses in wild birds. However, only a few studies have directly tested whether glucocorticoid concentrations begin to increase in the first few minutes of capture, and results have been equivocal (Romero and Reed 2005). Wingfield et al. (1982), Schoech et al. (1999), Sockman and Schwabl (2001) and Voslářová et al. (2008) indicated that corticosterone did not change in the first 3 min in their avian studies. In addition, Mizrahi et al. (2001) found changes in corticosterone titres between the 3 and 5 min mark. In contrast, Daws on and Howe (1983) reported a corticosterone increase after only $1 \mathrm{~min}$ and Romero and Reed (2005) approximately 2 min after capture. Since corticosterone concentrations vary within animal species,

Address for correspondence:

Doc. MVDr. Petr Chloupek, Ph.D.

University of Veterinary and Pharmaceutical Sciences

Faculty of Veterinary Hygiene and Ecology

Department of Veterinary Public Health and Toxicology

Palackeho 1 - 3, 61242 Brno, Czech Republic

Phone: +420 541562777

Fax : +420541562790

E-mail: chloupekp@vfu.cz

http://www.vfu.cz/acta-vet/actavet.htm 
comparisons between different species are problematic. It is not clear why species have such disparate baseline concentrations, but possible mechanisms include different numbers of glucocorticoid receptors in the target tissues, different affinities of those receptors for glucocorticoids, and different capacities and/or affinities of glucocorticoid binding proteins. Until these differences are characterized for each species, cross-species comparisons of glucocorticoid concentrations will be difficult to interpret (Romero 2004). Thus, research into stress response of each species is desirable.

Our study focused on the monitoring of biochemical indices in the common pheasant (Phasianus colchicus) during varying durations of pre-sampling handling. The common pheasant is a gallinaceous bird commonly occurring, and frequently hunted in Europe. In the Czech Republic, the common pheasant either lives in the wild or is kept at breeding facilities (pheasantries), from where it is released and subsequently hunted (Hauptmanová et al. 2006). Generally, in Europe the majority of driven pheasant shooting is supported by the release of captive-reared pheasants to increase the number of birds available to hunters (Dray cott et al. 2002, 2005). Although pheasant brooding and rearing practice is close to that of domestic poultry, significant differences in stress response of domestic poultry and pheasants, which are primarily wild animals, have already been observed (Voslářová et al. 2006; Suchý et al. 2007). Game birds have not been as thoroughly studied as poultry to date. Only a few studies have attempted to assess biochemical and haematological indicators in captive-reared pheasants and their changes (Straková et al. 2001; Hauptmanová et al. 2006; Mašek et al. 2007). The knowledge of baseline concentrations of the monitored variables and factors affecting their variability is essential for an accurate interpretation of results, especially when blood analysis is used in pheasants as a tool for evaluating stress.

\section{Materials and Methods}

Animals and treatment

Effects of varying periods of handling (capture, restraint, and blood sampling) on selected biochemical indices were monitored in a group of 8-9-month-old common pheasants (Phasianus colchicus) kept at a pheasantry in Jinačovice, Czech Republic. The pheasants were kept in external aviaries (40 birds per aviary), males and females together ( 1 male per 8 females). The number of birds in the pheasantry was approx. 600 (parent flock). The birds were fed commercial feeding compounds BŽ 1, BŽ 2 and BŽ (ZZN, Czech Republic). Randomly selected birds from 5 aviaries were caught individually with a net and used for the tests. Birds were carried with both hands, held in an upright position and carried into a separate room, where they had no visual contact with other birds. The time between capture and transfer to the place where blood sampling took place (sampling table) did not exceed $30 \mathrm{~s}$. Pheasants placed on the table were gently restrained by hand on their right side and blood samples (ca $4 \mathrm{ml})$ were taken from the vena basilica using a $0.9 \times 40 \mathrm{~mm}$ needle. The duration of restraint (including the collection of blood) varied among four groups of 10 pheasants ( 5 males and 5 females) each: Group 1.5 min, Group 3.0 min, Group $4.5 \mathrm{~min}$ and Group $6.0 \mathrm{~min}$. For biochemical examination, the blood samples were stabilized with heparin (final heparin concentration in blood samples $<1 \%$ ).

Biochemical examination

The heparinized blood was centrifuged at $800 \mathrm{~g}$ for $10 \mathrm{~min}$ and plasma samples were stored at $-80^{\circ} \mathrm{C}$ in Eppendorf test-tubes until analyses. Selected plasma biochemical indices: glucose, lactate, aspartate aminotransferase (AST) and cholesterol were measured in a Cobas EMira biochemical analyzer using commercial test kits (Biovendor - Laboratorni medicina a.s., Czech Republic). Plasma corticosterone concentration was measured using a commercial Corticosterone EIA Kit (Cayman Chemical, USA).

\footnotetext{
Statistics

Results were analysed using the statistical package Unistat 5.1. (Unistat Ltd. 1998). After the Shapiro-Wilk normality test and homogeneity of variance test, data with homogeneous variances (corticosterone, glucose, lactate, AST, cholesterol) was subjected to one-way ANOVA with pre-sampling handling time as a main effect, and subsequently, to a Tukey-HSD test (Zar 1999) for multiple comparisons in order to assess the significance of differences between all possible pairs of groups. To assess correlations in the experiment, Spearman rank correlation coefficients were calculated between exact times of handling duration recorded in sec (Group 1.5 min: within 90 s, Group 3.0 min: 91-180 s, Group 4.5 min: 181-270 s, Group 6.0 min: 271-360 s) and monitored biochemical indices.
} 
Table 1. Selected blood plasma biochemical indicators of pheasants handled for $1.5 \mathrm{~min}(\mathrm{n}=10)$, for $3 \mathrm{~min}$ $(\mathrm{n}=10)$, for $4.5 \min (\mathrm{n}=10)$ and $6 \min (\mathrm{n}=10)$ during blood sampling: Mean \pm SEM (Standard Error of Mean) and the significance of multiple comparisons tests.

\begin{tabular}{|l|c|c|c|c|}
\hline \multirow{2}{*}{ Indicator } & \multicolumn{4}{|c|}{ Handling duration } \\
\cline { 2 - 5 } & $1.5 \mathrm{~min}$ & $3.0 \mathrm{~min}$ & $4.5 \mathrm{~min}$ & $6 \mathrm{~min}$ \\
\hline $\begin{array}{l}\text { Corticosterone } \\
(\mathrm{ng} / \mathrm{ml})\end{array}$ & $7.65^{\mathrm{b}} \pm 1.35$ & $14.60^{\mathrm{a}} \pm 1.89$ & $20.68^{\mathrm{a}} \pm 1.18$ & $20.55^{\mathrm{a}} \pm 1.97$ \\
\hline $\begin{array}{l}\text { Glucose } \\
(\mathrm{mmol} / \mathrm{l})\end{array}$ & $19.02^{\mathrm{a}} \pm 0.32$ & $17.93^{\mathrm{b}} \pm 0.18$ & $17.82^{\mathrm{b}} \pm 0.17$ & $17.85^{\mathrm{b}} \pm 0.39$ \\
\hline $\begin{array}{l}\text { Lactate } \\
(\mathrm{mmol} / \mathrm{l})\end{array}$ & $11.60 \pm 0.94$ & $12.83 \pm 1.18$ & $14.16 \pm 1.11$ & $14.60 \pm 1.47$ \\
\hline $\begin{array}{l}\text { AST } \\
(\mu \mathrm{kat} / \mathrm{l})\end{array}$ & $5.93 \pm 0.42$ & $5.02 \pm 0.28$ & $5.04 \pm 0.28$ & $5.40 \pm 0.32$ \\
\hline $\begin{array}{l}\text { Cholesterol } \\
(\mathrm{mmol} / \mathrm{l})\end{array}$ & $3.43 \pm 0.13$ & $3.64 \pm 0.17$ & $3.39 \pm 0.21$ & $3.24 \pm 0.19$ \\
\hline
\end{tabular}

AST $=$ aspartate aminotransferase

Means within a row lacking a common superscript ${ }^{\text {a, }}$ differ.

\section{Results}

The results of the biochemical examinations in pheasants handled for $1.5 \mathrm{~min}, 3 \mathrm{~min}, 4.5$ min, and 6 min due to blood sampling are given in Table 1.

As follows from the results, pheasant handling (involving capture, restraint, and blood sampling) induced an elevation of plasma corticosterone concentration in the $3.0 \mathrm{~min}$ $(p<0.05), 4.5 \mathrm{~min}(p<0.001)$, and $6 \mathrm{~min}(p<0.001)$ groups in comparison with the birds that were caught, restrained and sampled within $1.5 \mathrm{~min}$. Birds that were handled for 3 $\mathrm{min}, 4.5 \mathrm{~min}$, and $6 \mathrm{~min}$ also showed significantly $(p<0.05)$ decreased glucose plasma concentrations compared to pheasants handled for $1.5 \mathrm{~min}$. No significant differences in corticosterone and glucose plasma levels were found between pheasants handled for $3 \mathrm{~min}$, $4.5 \mathrm{~min}$ and $6 \mathrm{~min}$. Other biochemical indices monitored in the experiment did not show

Table 2. Spearman rank correlation coefficients between handling duration (s) and monitored blood plasma biochemical indicators of pheasants

\begin{tabular}{|l|c|c|c|}
\hline Indicator & $\mathrm{n}$ & Correlation coef. & Significance $(p)$ \\
\hline Corticosterone $(\mathrm{ng} / \mathrm{ml})$ & 40 & 0.704 & $<0.001$ \\
\hline Glucose $(\mathrm{mmol} / \mathrm{l})$ & 40 & -0.463 & $<0.01$ \\
\hline Lactate $(\mathrm{mmol} / \mathrm{l})$ & 40 & 0.283 & $<0.05$ \\
\hline AST $(\mu \mathrm{kat} / \mathrm{l})$ & 40 & -0.269 & $<0.05$ \\
\hline Cholesterol $(\mathrm{mmol} / \mathrm{l})$ & 40 & -0.183 & $>0.05$ \\
\hline
\end{tabular}

AST $=$ aspartate aminotransferase differences among varying handling durations.

Correlations between the duration of handling and monitored biochemical indices in pheasants are given in Table 2.

The duration of handling (s) of pheasants was positively correlated with the plasma corticosterone concentration $(p<$ $0.001)$ and plasma lactate level $(p<0.05)$. Negative correlations were found between the duration of handling and glucose concentration $(p<0.01)$ and AST level $(p<0.05)$ in blood plasma.

No significant differences in the monitored biochemical indices were indicated between pheasant males and females in our experiment.

\section{Discussion}

For a variety of avian species, samples taken less than 2-3 min after capture are known to provide reliable baseline unstressed corticosterone concentrations (Wingfield et al. 1982; Schoech et al. 1999; Sockman and Schwabl 2001; Voslářová et al. 2008). But even if samples taken within 3 min of capture will likely reflect unstressed corticosterone concentrations, evidence suggests that corticosterone concentrations from samples 
collected near the end of that time frame could already be slightly elevated (Romero and Romero 2002). In our study, the level of corticosterone in blood samples of pheasants collected after $3 \mathrm{~min}$ of capture was twofold in comparison to blood samples taken within $1.5 \mathrm{~min}$. A highly significant positive correlation was found between the duration of handling pheasants and corticosterone plasma concentrations even if the differences among corticosterone concentrations in blood samples collected $3 \mathrm{~min}, 4.5 \mathrm{~min}$ and $6 \mathrm{~min}$ after capture were not significant. Similarly, Mizrahi et al. (2001) did not find changes in corticosterone concentrations in samples collected between 3 and 5 min. However, no samples were collected earlier than $3 \mathrm{~min}$ in their study and as follows from our results, significant changes in corticosterone concentrations can occur in a shorter period. Such an early increase in plasma corticosterone concentrations due to blood sampling per se in pheasants should be taken into account when studying the stress response of pheasants to other stressful stimuli or when assessing baseline concentrations. Although it is generally assumed that the glucocorticoid concentrations in samples taken in animals that were removed from the trap and bled within $3 \mathrm{~min}$ of capture represent baseline (prestressed) concentrations, such a conclusion is not valid in all species. Our results are in an agreement with Romero and Reed (2005) who reported that corticosterone titres were beginning to rise after approximately $2 \mathrm{~min}$ in seven of the 14 data sets collected from various species. To the contrary, on the basis of our results, we cannot support the presumption made by Mašek et al. (2007) that collecting blood samples in common pheasants within 6 min will avoid the changes in blood indicators due to the stress of capture, restraint and blood sampling. In our study, the duration of the handling of pheasants correlated not only with the corticosterone plasma concentration, but correlations were also found between the duration of handling and lactate, glucose and AST levels in blood plasma. Similarly to the timing of stress-induced changes in corticosterone levels, a significant decrease in glucose plasma concentrations was found in blood samples taken after 3 min of capture in comparison to blood samples of pheasants taken within $1.5 \mathrm{~min}$.

There are difficulties in capturing and taking blood samples quickly, especially from wild birds (Romero and Romero 2002). Unfortunately, speed is of the essence when studying corticosterone responses to stress. As follows from our study, corticosterone concentrations in blood samples taken after 3 min or later of capture cannot be considered as baseline levels in common pheasants. Moreover, our results indicate that other biochemical indices can be influenced by the duration of the handling (capture, restraint and blood sampling) of pheasants, and such changes can occur within 1.5-3 min of capture. To ensure that the levels of the monitored biochemical indices in common pheasants will not be affected by stress induced by pre-sampling handling, blood samples that were not collected within 1.5 min should be discarded.

\section{Vliv délky předodběrové manipulace na vybrané biochemické ukazatele u bažanta obecného (Phasianus colchicus)}

Vliv různé délky předodběrové manipulace (1,5 $\mathrm{min}, 3 \mathrm{~min}, 4,5 \mathrm{~min}, 6 \mathrm{~min})$ na vybrané biochemické ukazatele byl sledován na skupině bažantů obecných (Phasianus colchicus) ve věku 8-9 měsíců chovaných v bažantnici v Jinačovicích, ČR. Byla prokázána pozitivní korelace mezi délkou manipulace (zahrnující odchyt, držení a odběr krve) a hladinou kortikosteronu $(p<0,001)$ a laktátu $(p<0,05)$ a negativní korelace mezi délkou manipulace a hladinou glukózy $(p<0,01)$ a aspartátaminotransferázy $(p<0,05)$ v plazmě. Statisticky významně vyšší koncentrace kortikosteronu v plazmě a nižší koncentrace plazmatické glukózy byly zjištěny již u vzorků krve odebraných 3 min po odchytu ve srovnání se vzorky krve bažantů, u kterých doba předodběrové manipulace nepřekročila $1,5 \mathrm{~min}$. 


\section{Acknowledgement}

This research was supported by the Ministry of Education, Youth and Sports of the Czech Republic (MSM Project No. 6215712402).

\section{References}

Dawson A, Howe PD 1983: Plasma corticosterone in wild starlings (Sturnus vulgaris) immediately following capture and in relation to body weight during the annual cycle. Gen Comp Endocrinol 51: 303-308

Draycott RAH, Woodburn MIA, Carroll JP, Sage RB 2005: Effect of spring supplementary feeding on population density and breeding success of released pheasants Phasianus colchicus in Britain. Wildlife Biol 11: 177-182

Draycott RAH, Pock K, Carroll JP 2002: Sustainable management of a wild pheasant population in Austria. Z Jagdwiss 48: 346-353

Goymann W, Mostl E, Gwinner E 2002: Corticosterone metabolites can be measured noninvasively in excreta of European stonechats (Saxicola torquata rubicola). Auk 119: 1167-1173

Harper JM, Austad SN 2000: Fecal glucocorticoids: a nonivasive method of measuring adrenal activity in wild and captive rodents. Physiol Biochem Zool 73: 12-22

Hauptmanová K, Malý M, Literák I 2006: Changes of haematological parameters in common pheasant throughout the year. Vet Med 51: 29-34

Kotrschal K, Hirschenhauser K, Möstl E 1998: The relationship between social stress and dominance is seasonal in greylag geese. Anim Behav 55: 171-176

Mašek T, Severin K, Horvatek D, Janicki Z, Konjevic D, Slavica A, Mikulec Ž 2007: Serum parameters of intensively reared common pheasant (Phasianus colchicus) during fattening. Arch Geflugelkd 71: 135-138

Mizrahi DS, Holberton RL, Gauthreaux SA Jr 2001: Patterns of corticosterone secretion in migrating semipalmated sandpipers at a major spring stopover site. Auk 118: 79-91

Romero LM 2004: Physiological stress in ecology: lessons from biomedical research. Trends Ecol Evol 19: 249-255

Romero LM, Reed JM 2005: Collecting baseline corticosterone samples in the field: is under 3 min good enough? Comp Biochem Physiol A-Mol Integr Physiol 140: 73-79

Romero LM, Romero RC 2002: Corticosterone responses in wild birds: the importance of rapid initial sampling. Condor 104: 129-135

Romero LM, Ramenofsky M, Wingfield JC 1997: Season and migration alter the corticosterone response to capture and handling in an arctic migrant, the white-crowned sparrow (Zonotrichia leucophrys gambelii). Comp Biochem Physiol C-Toxicol Pharmacol 116: 171-177

Schoech SJ, Ketterson ED, Nolan V 1999: Exogenous testosterone and the adrenocortical response in dark-eyed juncos. Auk 116: 64-72

Sockman KW, Schwabl H 2001: Plasma corticosterone in nestling American kestrels: effects of age, handling stress, yolk androgens, and body condition. Gen Comp Endocrinol 122: 205-212

Straková E, Vitula F, Suchý P, Večerek V, Škaloud J 2001: Cholesterol concentration in yolks and blood plasma in five species of game birds (short communication). Arch Tierz-Arch Anim Breed 44: 339-343

Suchý P, Bedáňová I, Večerek V, Voslářová E, Pištěková V, Chloupek P, Vitula F 2007: Effects of transport stress and floor space reduction on selected biochemical indices in common pheasant (Phasianus colchicus). Arch Geflugelkd 71: 56-61

Unistat Ltd. 1998: Unistat statistical package for Windows, version 5.1. (London, GB).

Voslářová E, Bedáňová I, Večerek V, Pištěková V, Chloupek P, Suchý P 2006: Changes in haematological profile of common pheasant (Phasianus colchicus) induced by transit to pheasantry. Dtsch Tierarztl Wochenschr 113: 375-378

Voslářová E, Chloupek P, Bedáňová I, Suchý P, Pištěková V, Večerek V 2008: The effect of pre-sampling handling time on blood plasma biochemical parameters of broilers. Dtsch Tierarztl Wochenschr 115: 62-65

Wingfield JC, Romero LM 2001: Adrenocortical responses to stress and their modulation in free-living vertebrates. In: MCEWEN BS, GOODMAN HM (Eds): Handbook of Physiology. Oxford University Press, New York, pp. 211-234

Wingfield JC, Smith JP, Farner DS 1982: Endocrine responses of white-crowned sparrows to environmental stress. Condor 84: 399-409

Zar JH 1999: Biostatistical analysis. $4^{\text {th }}$ ed. Prentice Hall, Upper Saddle River, New Jersey, 663 p. 
